medRxiv preprint doi: https://doi.org/10.1101/2020.08.06.20162859; this version posted August 11, 2020. The copyright holder for this preprint (which was not certified by peer review) is the author/funder, who has granted medRxiv a license to display the preprint in It is made available under a CC-BY-NC-ND 4.0 International license .

\title{
Whole Care Home Testing for Covid-19 in a Local Authority Area in the United Kingdom
}

\section{Authors}

Anna Starling

Public Health Registrar

19 Market Road, Essex County Council, Chelmsford, CM1 1QH

annastarling@nhs.net

Eleanor White

Foundation Year Two Doctor

Essex County Council

Essex, United Kingdom

Eleanor.white6@nhs.net

Danny Showell

Public Health Consultant

Essex County Council

Essex, United Kingdom

David Wyllie

Consultant Microbiologist

Public Health England

Cambridge, United Kingdom

Smita Kapadia

Consultant in Communicable Disease Control

Public Health England

Cambridge, United Kingdom

Ravi Balakrishnan

Consultant in Health Protection

Public Health England

Cambridge, United Kingdom

\section{Word Count}

2590

NOTE: This preprint reports new research that has not been certified by peer review and should not be used to guide clinical practice. 
medRxiv preprint doi: https://doi.org/10.1101/2020.08.06.20162859; this version posted August 11, 2020. The copyright holder for this preprint (which was not certified by peer review) is the author/funder, who has granted medRxiv a license to display the preprint in It is made available under a CC-BY-NC-ND 4.0 International license .

\section{Abstract}

Objectives To describe the point prevalence of SARS-CoV-2 in care homes reporting low numbers of cases of COVID-19.

Design A cross-sectional study of care homes, ascertaining perceived disease burden using interviews with care home managers and SARS-CoV-2 RNA detection in residents and staff using nose and throat swabbing.

Setting 15 Care homes in Essex, United Kingdom, all of which had reported either zero or one case of COVID-19 to the Health Protection Team.

Participants 912 residents and staff of care homes were tested. Residents were eligible to be tested regardless of symptoms.

Main outcome measure Detection of SARS-CoV-2 in residents and staff.

Results In the 15 care homes studied, SARS-CoV-2 was detected in $23(5.2 \%)$ of 441 residents. Of these $23,21 / 23$ (91\%) were asymptomatic as reported by the care home managers. SARS-CoV-2 was detected in $8 / 471(1.7 \%)$ of staff. This differs from that in residents $(p=0.003)$.

Conclusions The study's findings suggest that symptoms, as reported by care home managers, are an insensitive method of defining the extent of SARS-CoV-2 infection in nursing homes. Viral detection from residents is more common than from staff. Microbiological screening is a more sensitive method for defining the extent of SARS-CoV-2 in care homes than managerial reporting of resident symptoms. 
medRxiv preprint doi: https://doi.org/10.1101/2020.08.06.20162859; this version posted August 11, 2020. The copyright holder for this

preprint (which was not certified by peer review) is the author/funder, who has granted medRxiv a license to display the preprint in It is made available under a CC-BY-NC-ND 4.0 International license .

\section{INTRODUCTION}

On the $31^{\text {st }}$ December 2019, a new cluster of pneumonia of unknown aetiology was first reported in Wuhan, China1. The cause was later identified as a novel coronavirus. The World Health Organisation named the virus severe acute respiratory syndrome coronavirus 2 (SARS-CoV-2) ${ }^{2}$. The first indigenous case in the United Kingdom (UK) with no direct or indirect travel links was confirmed on $28^{\text {th }}$ February $2020^{3}$ and the first COVID-19 death on $5^{\text {th }}$ March $2020^{4}$.

As the epidemic has progressed, there is evidence that residential care environments, including care homes, may be playing an increasing role in transmission and the generation of new cases ${ }^{5}$. As of 18 April, there were: 3,500 care home outbreaks cumulative, reported to Public Health England (PHE) in England, accounting for $22 \%$ of the care homes. A point-prevalence study in London of four care homes identified COVID-19 in $40 \%$ of residents, $43 \%$ of whom were asymptomatic and $18 \%$ had atypical symptoms ${ }^{6}$. Recent analysis of whole care home testing data for over $65 \mathrm{~s}$ in England between May and June 2020 (9081 homes) identified COVID-19 in 3.9\% of residents, $80.9 \%$ of whom were reported as asymptomatic ${ }^{7}$.

In April and May 2020 Essex County Council and PHE undertook a cross-sectional study in care homes (all ages) reporting low or no COVID-19 related illness among their residents and staff. The primary objective was to determine the proportion of care home residents and care home workers at work in whom SARS-CoV-2 can be detected to increase understanding of the prevalence of COVID19 in care home settings.

\section{METHODS}

Home survey: On the week commencing the $26^{\text {th }}$ April 2020, a COVID-19 outbreak had been reported in $23 \%$ of care homes in Essex. We identified 23 homes which had reported to the PHE Health Protection team either zero or one COVID-19 case(s). This was an opportunistic and pragmatic approach to intervene early to prevent transmission in homes and was therefore rooted in public health action. 21 of the 23 homes invited agreed to take part. Due to changes in testing capacity 16 homes were included in the final selection. The decision regarding which homes to include was made based on the order they were recruited, with the latter six homes being excluded.

Residents were eligible to be tested for SARs-CoV-2 regardless of symptoms. All care home staff who considered themselves to be fit to work were also eligible to be tested, including bank and agency staff. A PCR-based swab test was used to detect SARS-CoV-2 infection in the upper respiratory tract samples. Swabbing took place at the care homes between the $1^{\text {st }}$ and $14^{\text {th }}$ May 2020 , undertaken by a locally commissioned service that comprised trained nurses and health care assistants. 
medRxiv preprint doi: https://doi.org/10.1101/2020.08.06.20162859; this version posted August 11, 2020. The copyright holder for this

preprint (which was not certified by peer review) is the author/funder, who has granted medRxiv a license to display the preprint in It is made available under a CC-BY-NC-ND 4.0 International license.

Microbiological methods: In 14 homes the testing was via the regional Public Health laboratory. Two homes had testing done via a network of dedicated COVID-19 testing laboratories (Pillar 2). The assays used by these laboratories have similar performance and highly specific ${ }^{8}$.

Questionnaire: Care home managers were interviewed using a structured questionnaire in advance of swabbing to provide information on the total number of staff, residents, confirmed cases and deaths prior to participation. Following swabbing, care home managers were asked to provide basic demographic information for those swabbed (age, sex and ethnicity) and details of any symptomatic residents on the day of swabbing, based on the then UK Government case definition for COVID-19 of a new continuous cough or fever 9 .

Follow up: All residents and staff in whom SARS-CoV-2 was detected were followed up to understand if they developed symptoms up to 14 days following swabbing. This information was collected from the care home managers by the research team. Staff who were positive but asymptomatic were offered an additional PCR-based swab test ten days after testing to determine if SARS-CoV-2 could still be detected. (Figure 1)

Statistical methods: Results for residents and staff were examined separately. In addition, homes were stratified according to those with no confirmed (with at least one positive test result in staff or residents) or suspected cases, as reported to the research team by the care home manager, prior to the study swabbing. We compared counts of individuals with positive SARS-CoV-2 tests between residents and staff using a $x^{2}$ test with Yates' correction for Continuity (R 3.3.1).

\section{RESULTS}

The results from 15 care homes were included in the study, the results from the 16th care home were excluded due to selective sampling, as opposed to universal swabbing, of residents. (Figure 1).

The care homes included in the study ranged in size from ten to 67 residents. Three of the homes had no suspected or confirmed clinical cases in residents or staff prior to swab-testing taking place as reported to the research team (Table 1).

Overall, 912 staff and residents were tested for SARS-CoV-2 - 441/461 (95.7\%) of residents and $471 / 632(74.5 \%)$ of staff (Table 1). All care homes except two achieved greater than $90 \%$ resident coverage (Table 1). A total of $10(1.09 \%)$ swabs could not be analysed due to labelling or laboratory issues and were reported as void. By contrast, the coverage of staff differed markedly between care homes, from $100 \%$ in some homes, to very limited in others (\#11, 12 in Table 1). 
medRxiv preprint doi: https://doi.org/10.1101/2020.08.06.20162859; this version posted August 11, 2020. The copyright holder for this preprint (which was not certified by peer review) is the author/funder, who has granted medRxiv a license to display the preprint in It is made available under a CC-BY-NC-ND 4.0 International license .

Table 1 Characteristics of Care homes studied

\begin{tabular}{|c|c|c|c|c|c|c|c|}
\hline $\begin{array}{l}\text { Care } \\
\text { Home }\end{array}$ & $\begin{array}{l}\text { Residents } \\
\text { tested/tot } \\
\text { al (\%) }\end{array}$ & $\begin{array}{l}\text { Staff } \\
\text { tested/tot } \\
\text { al (\%) }\end{array}$ & $\begin{array}{l}\text { Case } \\
\text { reported } \\
\text { prior to } \\
\text { study }(\mathrm{Y} / \mathrm{N})\end{array}$ & $\begin{array}{l}\text { Age } \\
\text { range of } \\
\text { resident } \\
\text { s (mean) }\end{array}$ & $\begin{array}{l}\text { Proportio } \\
\text { n female } \\
\text { (residents } \\
\text { ) }\end{array}$ & $\begin{array}{l}\text { Care for } \\
\text { adults } \\
\text { under } 65 ? \\
(\mathrm{Y} / \mathrm{N})\end{array}$ & $\begin{array}{l}\text { Care for } \\
\text { adults } \\
\text { with } \\
\text { dementia } \\
?(\mathrm{Y} / \mathrm{N})\end{array}$ \\
\hline 1 & $\begin{array}{l}35 / 37 \\
(94.6 \%)\end{array}$ & $\begin{array}{l}12 / 44 \\
(27.3 \%)\end{array}$ & $\bar{Y}$ & $\begin{array}{l}\text { Not } \\
\text { available }\end{array}$ & $\begin{array}{l}\text { Not } \\
\text { available }\end{array}$ & $\bar{Y}$ & $\mathrm{Y}$ \\
\hline 2 & $\begin{array}{l}39 / 39 \\
(100 \%)\end{array}$ & $\begin{array}{l}42 / 43 \\
(97.7 \%)\end{array}$ & $Y$ & $\begin{array}{l}76-99 \\
(87.8)\end{array}$ & $\begin{array}{l}\text { Not } \\
\text { available }\end{array}$ & $\mathrm{N}$ & $\mathrm{N}$ \\
\hline 3 & $\begin{array}{l}32 / 33 \\
(97.0 \%)\end{array}$ & $\begin{array}{l}44 / 44 \\
(100 \%)\end{array}$ & $\mathrm{Y}$ & $\begin{array}{l}68-99 \\
(86.7)\end{array}$ & $72.7 \%$ & $\mathrm{~N}$ & $\mathrm{~N}$ \\
\hline 4 & $\begin{array}{l}31 / 33 \\
(93.9 \%)\end{array}$ & $\begin{array}{l}91 / 91 \\
(100 \%)\end{array}$ & $\mathrm{Y}$ & $\begin{array}{l}18-57 \\
(36.1)\end{array}$ & $54.8 \%$ & $\mathrm{Y}$ & $\mathrm{N}$ \\
\hline 5 & $\begin{array}{l}33 / 34 \\
(97.1 \%)\end{array}$ & $\begin{array}{l}24 / 31 \\
(77.4 \%)\end{array}$ & $Y$ & $\begin{array}{l}79-100 \\
(89.9)\end{array}$ & $75.8 \%$ & $\mathrm{~N}$ & $Y$ \\
\hline 6 & $\begin{array}{l}45 / 45 \\
(100 \%)\end{array}$ & $\begin{array}{l}48 / 48 \\
(100 \%)\end{array}$ & $\mathrm{Y}$ & $\begin{array}{l}77-103 \\
(90.5)\end{array}$ & $77.8 \%$ & $\mathrm{~N}$ & $\mathrm{~N}$ \\
\hline 7 & $\begin{array}{l}19 / 19 \\
(100 \%)\end{array}$ & $\begin{array}{l}46 / 46 \\
(100 \%)\end{array}$ & $\mathrm{Y}$ & $\begin{array}{l}\text { Not } \\
\text { available }\end{array}$ & $\begin{array}{l}\text { Not } \\
\text { available }\end{array}$ & $\mathrm{Y}$ & $\mathrm{Y}$ \\
\hline 8 & $\begin{array}{l}65 / 67 \\
(97.0 \%)\end{array}$ & $\begin{array}{l}70 / 97 \\
(72.2 \%)\end{array}$ & $\bar{Y}$ & $\begin{array}{l}61-106 \\
(87.3)\end{array}$ & $66.1 \%$ & $\mathrm{~N}$ & $\mathrm{~N}$ \\
\hline 9 & $\begin{array}{l}22 / 24 \\
(91.7 \%)\end{array}$ & $\begin{array}{l}12 / 22 \\
(54.5 \%)\end{array}$ & $Y$ & $\begin{array}{l}67-94 \\
(86.4)\end{array}$ & $68.1 \%$ & $\mathrm{~N}$ & $Y$ \\
\hline 10 & $\begin{array}{l}24 / 28 \\
(85.7 \%)\end{array}$ & $\begin{array}{l}8 / 20 \\
(40.0 \%)\end{array}$ & $\mathrm{Y}$ & $\begin{array}{l}72-98 \\
(82.3)\end{array}$ & $66.7 \%$ & $\mathrm{~N}$ & $\bar{Y}$ \\
\hline 11 & $\begin{array}{l}14 / 19 \\
(73.7 \%)\end{array}$ & $\begin{array}{l}0 / 28 \\
(0 \%)\end{array}$ & $\mathrm{Y}$ & $\begin{array}{l}70-91 \\
(83.3)\end{array}$ & $71.4 \%$ & $\mathrm{Y}$ & $\mathrm{Y}$ \\
\hline 12 & $\begin{array}{l}16 / 17 \\
(94.1 \%)\end{array}$ & $\begin{array}{l}5 / 30 \\
(16.7 \%)\end{array}$ & $Y$ & $\begin{array}{l}\text { Not } \\
\text { available }\end{array}$ & $\begin{array}{l}\text { Not } \\
\text { available }\end{array}$ & $\mathrm{N}$ & $\mathrm{Y}$ \\
\hline 13 & $\begin{array}{l}42 / 42 \\
(100 \%)\end{array}$ & $\begin{array}{l}46 / 60 \\
(76.7 \%)\end{array}$ & $\mathrm{N}$ & $\begin{array}{l}\text { 65-102 } \\
(78.4)\end{array}$ & $61.9 \%$ & $\mathrm{~N}$ & $\bar{Y}$ \\
\hline 14 & $\begin{array}{l}14 / 14 \\
(100 \%)\end{array}$ & $\begin{array}{l}18 / 18 \\
(100 \%)\end{array}$ & $\mathrm{N}$ & $\begin{array}{l}72-95 \\
(85.1)\end{array}$ & $78.6 \%$ & $\mathrm{~N}$ & $\bar{Y}$ \\
\hline 15 & $\begin{array}{l}10 / 10 \\
(100 \%)\end{array}$ & $\begin{array}{l}5 / 10 \\
(50.0 \%)\end{array}$ & $\mathrm{N}$ & $\begin{array}{l}23-87 \\
(63.3)\end{array}$ & $40.0 \%$ & $\mathrm{Y}$ & $\mathrm{N}$ \\
\hline
\end{tabular}

Overall SARS-CoV-2 was detected in 31 (3.4\%) of all tested. Of the 441 tests performed on residents, SARS-CoV-2 was detected in $23(5.2 \%)$. For residents with positive results, 21 (91.3\%) were reported by care home managers as being asymptomatic and two (8.7\%) as symptomatic at the time of testing (Table 2). Of the 21 residents reported as positive, none went on to develop symptoms in the next two weeks.

Of the 471 tests performed on staff, SARS-CoV-2 was detected in $8(1.70 \%)$. This differs from that in residents ( $p=0.003$ ). All staff with positive results were reported to be asymptomatic on the day of testing (Table 2), and all were negative on retesting between day nine and eleven. 
medRxiv preprint doi: https://doi.org/10.1101/2020.08.06.20162859; this version posted August 11, 2020. The copyright holder for this preprint (which was not certified by peer review) is the author/funder, who has granted medRxiv a license to display the preprint in It is made available under a CC-BY-NC-ND 4.0 International license .

Table 2 Results of Testing

\begin{tabular}{|l|l|r|r|l|l|l|r|}
\hline & $\begin{array}{l}\text { Total } \\
\text { swabbed } \\
\text { for SARS- } \\
\text { CoV-2 }\end{array}$ & Uptake & $\begin{array}{l}\text { Total } \\
\text { SARS-CoV- } \\
\text { 2 positive }\end{array}$ & $\begin{array}{l}\text { Total } \\
\text { SARS-CoV- } \\
\text { 2 positive } \\
\text { who were } \\
\text { asymptoma } \\
\text { tic at the } \\
\text { time of } \\
\text { testing }\end{array}$ & $\begin{array}{l}\text { Total } \\
\text { SARS-CoV- } \\
\text { 2 positive } \\
\text { who were } \\
\text { symptomati } \\
\text { cat the } \\
\text { time of } \\
\text { testing }\end{array}$ & $\begin{array}{l}\text { Total } \\
\text { SARS-CoV- } \\
\text { 2 positive } \\
\text { who } \\
\text { subsequent } \\
\text { ly } \\
\text { developed } \\
\text { symptoms }\end{array}$ & $\begin{array}{l}\text { Total } \\
\text { SARS-CoV- } \\
\text { 2 positive } \\
\text { at day 9-11 } \\
\text { retest }\end{array}$ \\
\hline $\begin{array}{l}\text { Residents } \\
(\mathbf{n = 4 6 1 )}\end{array}$ & 441 & $95.7 \%$ & $23(5.2 \%)$ & $21(91.3 \%)$ & $2(8.7 \%)$ & 0 & \\
\hline $\begin{array}{l}\text { Staff } \\
(n=632)\end{array}$ & 471 & $74.5 \%$ & $8(1.7 \%)$ & $8(100 \%)$ & $0(0 \%)$ & & 0 \\
\hline
\end{tabular}

The three homes that had no suspected or confirmed clinical cases in residents or staff prior to swabtesting taking place had no positive results in staff or residents with staff uptake between 50 and $100 \%$.

\section{DISCUSSION}

In the 15 care homes studied, near complete coverage of residents was achieved (95.7\%), with a lower portion of care home staff screened ( $74.5 \%$, but with wide variation between homes). SARSCoV-2 was detected in $5.2 \%$ of residents, nine out of ten of who were asymptomatic at the time of swabbing, as reported by the care home managers. The point-prevalence of SARS-CoV-2 was lower in care home staff than residents at $1.7 \%$ but this may have been affected by the screening policy, which excluded ill staff from attending.

The study found a lower proportion of positive SARS-CoV-2 residents in care homes than in prior descriptive studies in the UK ${ }^{6}$ and United States ${ }^{11}$, but with a higher proportion of those who were detected being reported by care home managers as asymptomatic. The study found a slightly higher prevalence of SARS-COV-2 in residents than in the Whole Care Testing programme with a higher proportion of positive residents being asymptomatic ${ }^{7}$ This may result from different susceptibilities to severe clinical disease in different care homes, differences in infection to testing interval, survivorship bias (that some individuals had died prior to the cross-sectional study) or differences in ascertainment of illness in different homes. As well as the studies taking place at different points in the epidemic.

Care home settings appear to be particularly susceptible to COVID-19 outbreaks. Many residents are vulnerable to severe infection due to their advanced age and multiple co-morbidities and much is still unknown about the transmission of COVID-19 within care homes, despite their vulnerability ${ }^{11}$. In this study, the difference between the proportion of individuals virologically positive (5.2\%), and those considered symptomatic by care home managers $(\sim 0.5 \%)$ is striking. This is important because, in the absence of molecular surveillance of SARS-CoV-2 ingress into care homes, public health surveillance has been reliant on symptom-based surveillance and reporting by care home and their 
medRxiv preprint doi: https://doi.org/10.1101/2020.08.06.20162859; this version posted August 11, 2020. The copyright holder for this preprint (which was not certified by peer review) is the author/funder, who has granted medRxiv a license to display the preprint in It is made available under a CC-BY-NC-ND 4.0 International license .

managers. This report suggests this activity, formerly a backbone of public health surveillance, may be very insensitive.

As of July 2020, the Department for Health and Social Care announced there will be a roll out of weekly staff testing and testing of residents every 28 day out days in care homes without reported outbreaks. The policy will be reviewed in September 2020. As lockdown restrictions continue to be lifted this study's findings adds to the evidence for this routine molecular surveillance to be instituted.

\section{REFERENCE LIST}

1. World Health Organisation, Pneumonia of unknown cause- China [Internet]. 2020 January 5. Available from: https://www.who.int/csr/don/05-january-2020-pneumonia-of-unkown-causechina/en/ [accessed 01/06/20].

2. World Health Organisation, Naming the coronavirus disease (COVID-19) and the virus that causes it [Internet]. 2020. Available from: https://www.who.int/emergencies/diseases/novelcoronavirus-2019/technical-guidance/naming-the-coronavirus-disease-(covid-2019)-and-thevirus-that-causes-it [cited 01/06/20]

3. Whitty, C. Chief Medical Officer for England announces a new case of novel coronavirus: 28 February 2020 [Internet]. HMSO; 2020. Available from:

https://www.gov.uk/government/news/cmo-for-england-announces-a-new-case-of-novelcoronavirus-28-february-2020 [accessed 03/06/20]

4. Whitty, C. Chief Medical Officer for England announces first death of patient with COVID-19 [Internet]. HMSO; 2020. Available from: https://www.gov.uk/government/news/cmo-forengland-announces-first-death-of-patient-with-covid-19 [accessed 03/06/20]

5. World Health Organisation, WHO/Europe guidance shows more can be done to protect people in need of long-term care during the COVID-19 pandemic [Internet]. 2020. Available from https://www.euro.who.int/en/health-topics/health-emergencies/coronavirus-covid19/news/news/2020/5/new-whoeurope-guidance-shows-more-can-be-done-to-protect-peoplein-need-of-long-term-care-during-the-covid-19-pandemic [cited 03/06/20]

6. Graham N S N, Junghans C, Downes R et al. SARS-CoV-2 infection, clinical features and outcome of COVID-19 in United Kingdom nursing homes. J. Infect. 2020. https://doi.org/10.1016/i.jinf.2020.05.073

7. Department of Health and Social Care, Vivaldi COVID-19 Care Home Study Report. [Internet]. 2020. Available https://www.gov.uk/government/publications/vivaldi-1-coronaviruscovid-19-care-homes-study-report/vivaldi-1-covid-19-care-homes-study-report [cited 09/07/20]

8. Caruana G, Croxatta A, Coste AT, et al. Diagnostic strategies for SARS-CoV-2 infection and interpretation of microbiological results. Clin. Microbiol. Infect. 2020. https://doi.org/10.1016/j.cmi.2020.06.019

9. Public Health England. COVID-19: investigation and initial clinical management of possible cases [Internet]. HMSO; 2020. [Updated 22 May 2020]. Available from: 
medRxiv preprint doi: https://doi.org/10.1101/2020.08.06.20162859; this version posted August 11, 2020. The copyright holder for this preprint (which was not certified by peer review) is the author/funder, who has granted medRxiv a license to display the preprint in It is made available under a CC-BY-NC-ND 4.0 International license .

https://www.gov.uk/government/publications/wuhan-novel-coronavirus-initial-investigation-ofpossible-cases/investigation-and-initial-clinical-management-of-possible-cases-of-wuhannovel-coronavirus-wn-cov-infection\#criteria [accessed 15/06/20]

10. Kimball A, Hatfield KM, Arons M, et al. Asymptomatic and Presymptomatic SARS-CoV-2 Infections in Residents of a Long-Term Care Skilled Nursing Facility - King County, Washington, March 2020. MMWR Morb Mortal Wkly Rep. 2020;69(13):377-381. doi:10.15585/mmwr.mm6913e1

11. Gordon AL, Franklin M, Bradshaw L, et al. Health status of UK care home residents: a cohort study. Age Ageing. 2014;43(1):97-103. doi:10.1093/ageing/aft077

12. Department of Health and Social Care, Regular retesting rolled out for care home staff and residents. [Internet]. 2020 available from https://www.gov.uk/government/news/regularretesting-rolled-out-for-care-home-staff-and-residents. Accessed [06/07/20] 
medRxiv preprint doi: https://doi.org/10.1101/2020.08.06.20162859; this version posted August 11, 2020. The copyright holder for this preprint (which was not certified by peer review) is the author/funder, who has granted medRxiv a license to display the preprint in It is made available under a CC-BY-NC-ND 4.0 International license

\section{Figures}

Figure 1: Care Home Testing Process

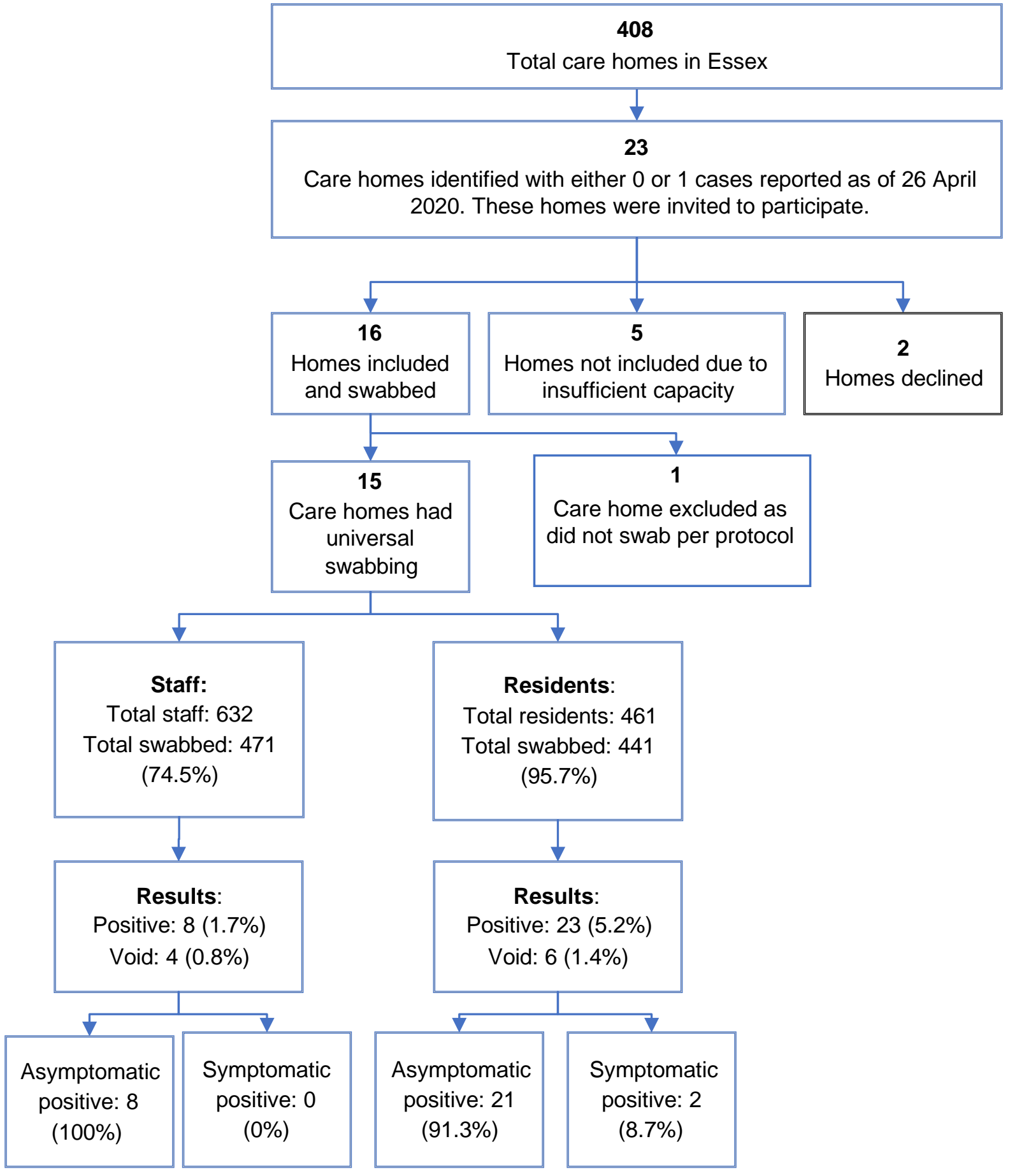


medRxiv preprint doi: https://doi.org/10.1101/2020.08.06.20162859; this version posted August 11, 2020. The copyright holder for this preprint (which was not certified by peer review) is the author/funder, who has granted medRxiv a license to display the preprint in It is made available under a CC-BY-NC-ND 4.0 International license .

\section{Acknowledgements}

\section{Ethics}

This study has been subject to an internal ethical and governance review at Public Health England which considered the study design, content and feasibility. The review also covered all legal, financial, regulatory and ethical considerations. As a result of this review, the study was categorized as a public health practice study that was being undertaken to help to manage the COVID 19 outbreak. As no ethical issues were identified it was decided that consideration by an ethics committee would not be necessary

\section{Patient and Public Involvement}

Patients and the public were not involved in the design of this study as it formed part of the local response to the COVID-19 pandemic.

\section{Funding}

Funding was through Essex County Council and Public Health England.

\section{Transparency Declaration}

The lead author affirms that the manuscript is an honest, accurate, and transparent account of the study; no important aspects of the study have been omitted; and any discrepancies from the study as originally planned have been explained.

\section{Competing Interests}

No competing interests to declare 
Table 1 Characteristics of Care homes studied

\begin{tabular}{|c|c|c|c|c|c|c|c|}
\hline $\begin{array}{l}\text { Care } \\
\text { Home }\end{array}$ & $\begin{array}{l}\text { Residents } \\
\text { tested/tot } \\
\text { al (\%) }\end{array}$ & $\begin{array}{l}\text { Staff } \\
\text { tested/tot } \\
\text { al (\%) }\end{array}$ & $\begin{array}{l}\text { Case } \\
\text { reported } \\
\text { prior to } \\
\text { study } \\
(\mathrm{Y} / \mathrm{N})\end{array}$ & $\begin{array}{l}\text { Age range } \\
\text { of } \\
\text { residents } \\
\text { (mean) }\end{array}$ & $\begin{array}{l}\text { Proportion } \\
\text { female } \\
\text { (residents } \\
\text { ) }\end{array}$ & $\begin{array}{l}\text { Care for } \\
\text { adults } \\
\text { under } 65 ? \\
(\mathrm{Y} / \mathrm{N})\end{array}$ & $\begin{array}{l}\text { Care for } \\
\text { adults } \\
\text { with } \\
\text { dementia } \\
?(\mathrm{Y} / \mathrm{N})\end{array}$ \\
\hline 1 & $\begin{array}{l}35 / 37 \\
(94.6 \%)\end{array}$ & $\begin{array}{l}12 / 44 \\
(27.3 \%)\end{array}$ & $Y$ & $\begin{array}{l}\text { Not } \\
\text { available }\end{array}$ & $\begin{array}{l}\text { Not } \\
\text { available }\end{array}$ & $Y$ & $Y$ \\
\hline 2 & $\begin{array}{l}39 / 39 \\
(100 \%)\end{array}$ & $\begin{array}{l}42 / 43 \\
(97.7 \%)\end{array}$ & Y & $\begin{array}{l}76-99 \\
(87.8)\end{array}$ & $\begin{array}{l}\text { Not } \\
\text { available }\end{array}$ & $N$ & $N$ \\
\hline 3 & $\begin{array}{l}32 / 33 \\
(97.0 \%)\end{array}$ & $\begin{array}{l}44 / 44 \\
(100 \%)\end{array}$ & $Y$ & $\begin{array}{l}68-99 \\
(86.7) \\
\end{array}$ & $72.7 \%$ & $N$ & $N$ \\
\hline 4 & $\begin{array}{l}31 / 33 \\
(93.9 \%)\end{array}$ & $\begin{array}{l}91 / 91 \\
(100 \%)\end{array}$ & $Y$ & $\begin{array}{l}18-57 \\
(36.1) \\
\end{array}$ & $54.8 \%$ & Y & $N$ \\
\hline 5 & $\begin{array}{l}33 / 34 \\
(97.1 \%) \\
\end{array}$ & $\begin{array}{l}24 / 31 \\
(77.4 \%) \\
\end{array}$ & Y & $\begin{array}{l}79-100 \\
(89.9)\end{array}$ & $75.8 \%$ & $N$ & $Y$ \\
\hline 6 & $\begin{array}{l}45 / 45 \\
(100 \%)\end{array}$ & $\begin{array}{l}48 / 48 \\
(100 \%)\end{array}$ & $Y$ & \begin{tabular}{|l}
$77-103$ \\
$(90.5)$ \\
\end{tabular} & $77.8 \%$ & $N$ & $N$ \\
\hline 7 & $\begin{array}{l}19 / 19 \\
(100 \%)\end{array}$ & $\begin{array}{l}46 / 46 \\
(100 \%)\end{array}$ & $Y$ & $\begin{array}{l}\text { Not } \\
\text { available }\end{array}$ & $\begin{array}{l}\text { Not } \\
\text { available }\end{array}$ & $Y$ & $Y$ \\
\hline 8 & $\begin{array}{l}65 / 67 \\
(97.0 \%)\end{array}$ & $\begin{array}{l}70 / 97 \\
(72.2 \%)\end{array}$ & Y & $\begin{array}{l}61-106 \\
(87.3)\end{array}$ & $66.1 \%$ & $N$ & $N$ \\
\hline 9 & $\begin{array}{l}22 / 24 \\
(91.7 \%)\end{array}$ & $\begin{array}{l}12 / 22 \\
(54.5 \%)\end{array}$ & $Y$ & \begin{tabular}{|l|}
$67-94$ \\
$(86.4)$ \\
\end{tabular} & $68.1 \%$ & $N$ & $Y$ \\
\hline 10 & $\begin{array}{l}24 / 28 \\
(85.7 \%) \\
\end{array}$ & $\begin{array}{l}8 / 20 \\
(40.0 \%)\end{array}$ & $Y$ & \begin{tabular}{|l|}
$72-98$ \\
$(82.3)$ \\
\end{tabular} & $66.7 \%$ & $N$ & $Y$ \\
\hline 11 & $\begin{array}{l}14 / 19 \\
(73.7 \%)\end{array}$ & $\begin{array}{l}0 / 28 \\
(0 \%)\end{array}$ & $Y$ & $\begin{array}{l}70-91 \\
(83.3)\end{array}$ & $71.4 \%$ & $Y$ & $Y$ \\
\hline 12 & $\begin{array}{l}16 / 17 \\
(94.1 \%) \\
\end{array}$ & $\begin{array}{l}5 / 30 \\
(16.7 \%) \\
\end{array}$ & $Y$ & $\begin{array}{l}\text { Not } \\
\text { available }\end{array}$ & $\begin{array}{l}\text { Not } \\
\text { available }\end{array}$ & $N$ & $Y$ \\
\hline 13 & $\begin{array}{l}42 / 42 \\
(100 \%)\end{array}$ & $\begin{array}{l}46 / 60 \\
(76.7 \%)\end{array}$ & $N$ & $\begin{array}{l}65-102 \\
(78.4)\end{array}$ & $61.9 \%$ & $N$ & $\mathrm{Y}$ \\
\hline 14 & $\begin{array}{l}14 / 14 \\
(100 \%)\end{array}$ & $\begin{array}{l}18 / 18 \\
(100 \%)\end{array}$ & $N$ & $\begin{array}{l}72-95 \\
(85.1) \\
\end{array}$ & $78.6 \%$ & $N$ & $\mathrm{Y}$ \\
\hline 15 & $\begin{array}{l}10 / 10 \\
(100 \%)\end{array}$ & $\begin{array}{l}5 / 10 \\
(50.0 \%)\end{array}$ & $N$ & $\begin{array}{l}23-87 \\
(63.3)\end{array}$ & $40.0 \%$ & $Y$ & $N$ \\
\hline
\end{tabular}


Table 2 Results of Screening

\begin{tabular}{|l|l|l|l|l|l|l|l|}
\hline & $\begin{array}{l}\text { Total } \\
\text { swabbed } \\
\text { for SARS- } \\
\text { CoV-2 }\end{array}$ & Uptake & $\begin{array}{l}\text { Total SARS } \\
\text { CoV-2 } \\
\text { positive }\end{array}$ & $\begin{array}{l}\text { Total SARS- } \\
\text { CoV-2 positive } \\
\text { who were } \\
\text { asymptomatic } \\
\text { at the time of } \\
\text { testing }\end{array}$ & $\begin{array}{l}\text { Total SARS- } \\
\text { CoV-2 } \\
\text { positive who } \\
\text { were } \\
\text { symptomatic } \\
\text { at the time of } \\
\text { testing }\end{array}$ & $\begin{array}{l}\text { Total SARS- } \\
\text { CoV-2 positive } \\
\text { who } \\
\text { subsequently } \\
\text { developed } \\
\text { symptoms }\end{array}$ & $\begin{array}{l}\text { Total SARS } \\
\text { CoV-2 } \\
\text { positive at } \\
\text { day 9-11 } \\
\text { retest }\end{array}$ \\
\hline $\begin{array}{l}\text { Residents } \\
(\mathrm{n}=\mathbf{4 6 1})\end{array}$ & 441 & $95.7 \%$ & $23(5.2 \%)$ & $21(91.3 \%)$ & $2(8.7 \%)$ & 0 & N/A \\
\hline Staff & 471 & $74.5 \%$ & $8(1.7 \%)$ & $8(100 \%)$ & $0(0 \%)$ & 0 & 0 \\
\hline$(n=632)$
\end{tabular}


Total care homes in Essex

\section{3}

Care homes identified with either 0 or 1 cases reported as of 26 April 2020. These homes were invited to participate.

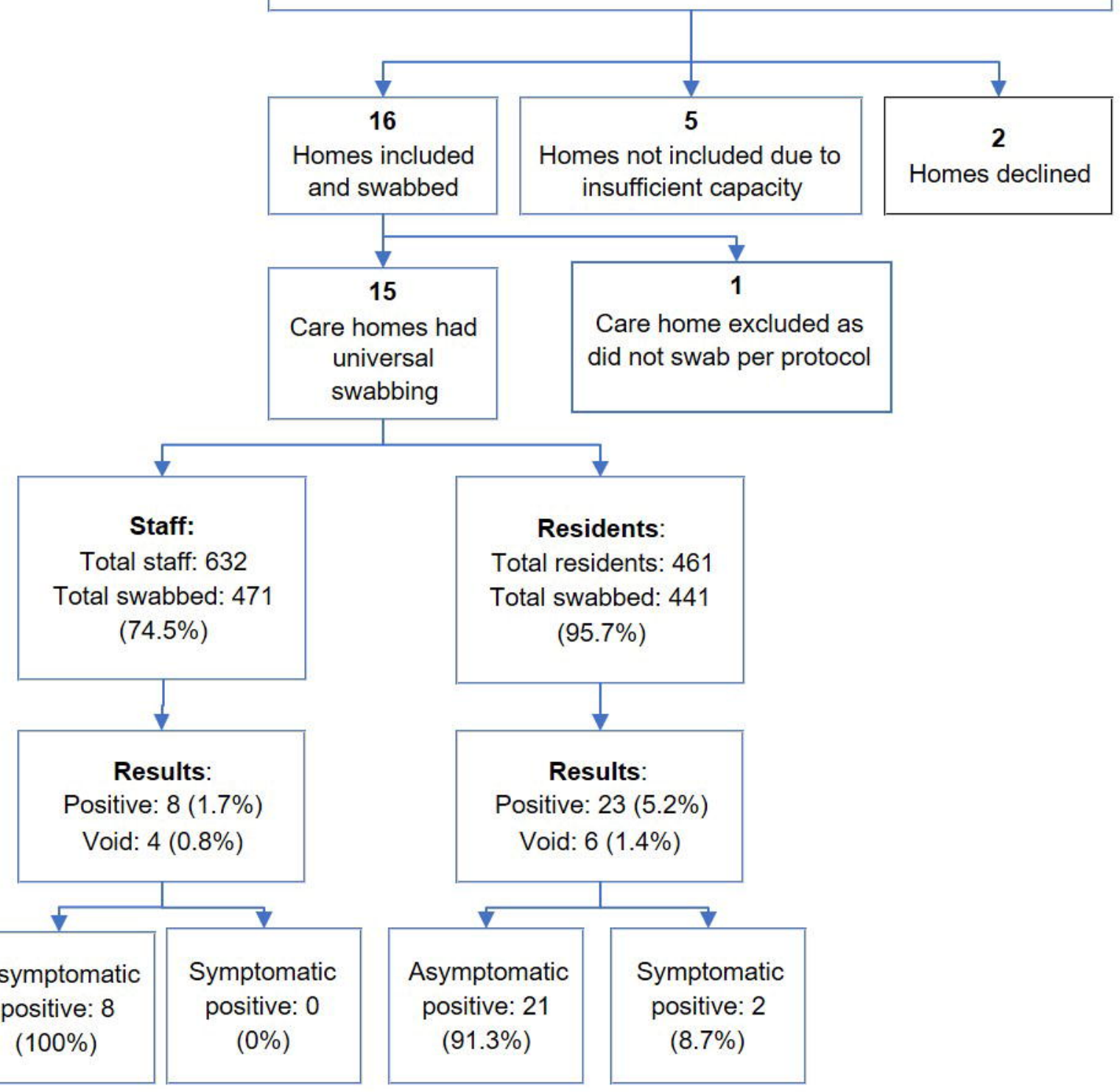

